\title{
DAMPAK PENCEMARAN LOGAM TIMAH HITAM (Pb) TERHADAP KESEHATAN
}

\author{
Suksmerri*
}

\section{Pendahuluan}

Keracunan logam berat $\mathrm{Pb}$ yang berasal dari lingkungan ambien pada dekade terakhir telah merupakan resiko kesehatan lingkungan utama yang dihadapi baik di negara-negara maju maupun yang sedang berkembang. $\mathrm{Pb}$ memasuki tubuh dapat melalui saluran pernafasan, saluran cerna, bahkan melalui kontak dermal. Namun jalur penting untuk paparan $\mathrm{Pb}$ terhadap manusia adalah melalui pernafasan (inhalasi). Paparan $\mathrm{Pb}$ yang berlangsung lama dapat mengakibatkan gangguan terhadap berbagai sistem organ seperti darah, sistem syaraf, ginjal, sistem reproduksi dan saluran cerna (Manahan ,1992).

Sumber-sumber $\mathrm{Pb}$ dapat berasal dari alam dan sebagai akibat antropogenik. Secara alamiah $\mathrm{Pb}$ di lingkungan berasal dari pelapukan geologis dan letusan gunung berapi. Aktivitas antropogenik masuknya $\mathrm{Pb}$ ke lingkungan berasal dari berbagai aktivitas antara lain pertambangan,peleburan, dan sebagai hasil samping dari industri accu (aki), kabel,pigmen, produksi baja serta dari hasil pembakaran bahan bakar bensin yang mengandung zat aditif TEL dan TML.Diperkirakan dari kegiatan pertambangan dan peleburan jumlah $\mathrm{Pb}$ yang diemisikan ke dalam lingkungan sekiatar 126.000 ton/tahun, dan dari kegiatan lainnya sekitar 3 juta ton/tahun (Manahan, 1992).

Udara yang tercemar dengan partikel dapat menyebabkan gangguan kesehatan yang berbeda tingkatan dan jenisnya, tergantung dari macam, ukuran dan komposisi kimianya.Gangguan tersebut utama terjadi pada fungsi faal dari organ tubuh seperti paru-paru dan pembuluh darah. Pencemaran udara karena partikel debu biasanya menyebabkan penyakit pernafasan kronis seperti bronchitis kronis, emfiesma paru, asma bronchial dan bahkan kanker paru

Menurut Palar (1994), konsentrasi Pb yang tinggi di udara dapat mengganggu pembentukan sel darah merah. Gejala keracunan dini mulai ditunjukkan dengan terganggunya fungsi enzim untuk pembentukan sel darah merah, pada akhirnya dapat menyebabkan gangguan kesehatan lainnya seperti anemia, kerusakan ginjal.

Beberapa penelitian telah memperlihatkan cemaran akibat $\mathrm{Pb}$ ke lingkungan dengan konsentrasi yang tinggi. Cemaran logam $\mathrm{Pb}$ terbanyak dilakukan pada lingkungan perairan, untuk cemaran di lingkungan udara telah dilakukan oleh Browne, dalam penelitian tersebut ditemukan bahwa tingkat cemaran $\mathrm{Pb}$ udara tertinggi di Kotamadya Semarang terdapat di Tambaklorok Kecamatan Semarang Utara, pada musim kemarau rata-rata $8,41 \mu \mathrm{g} / \mathrm{m}^{3}$ dan dimusim penghujan $10,85 \mu \mathrm{g} / \mathrm{m}^{3}$. Konsentrasi tersebut telah jauh melampau nilai ambang baku mutu lingkungan maksimal $2 \mu \mathrm{g} / \mathrm{m}^{3}$ per 24 jam (PP RI No. 41 Tahun 1999, tentang Pengendalian Pencemaran Udara).

Penelitian lain memperlihatkan adanya pengaruh gas buang kendaraan bermotor terhadap konsentrasi timbal darah yang berlokasi di Yokyakarta dengan 3 titik pengambilan sampel, konsentrasi $\mathrm{Pb}$ di lokasi 1 menunjukkan 0,486 $\mu \mathrm{g} / \mathrm{m}^{3}$, kadar $\mathrm{Pb}$ darah pedagang sebesar 49,59 $\mu \mathrm{g} / 100 \mathrm{ml}$. Lokasi 2 konsentrasi $\mathrm{Pb}$ adalah $33,63 \mu \mathrm{g} / \mathrm{m}^{3}$, serta $\mathrm{Pb}$ dalam darah pedagang $24,17 \mu \mathrm{g} / 100$ ml. Lokasi 3 konsentrasi Pb sebesar $0,45 \mu \mathrm{g} / \mathrm{m}^{3}$, serta $\mathrm{Pb}$ dalam darah pedagang adalah $33,53 \mu \mathrm{g} / 100 \mathrm{ml}$ (Widiati,1992)

Dari latar belakang diatas maka perlu dilakukan suatu kajian melalui studi literatur tentang keberadaan $\mathrm{Pb}$ di lingkungan, dengan meningkatnya $\mathrm{Pb}$ di lingkungan akan mengakibatkan gangguan kesehatan manusia, yang selanjutnya perlu dilakukan pemeriksaan $\mathrm{Pb}$ dalam darah, dengan tujuan untuk melihat apakah seseorang itu telah keracunan $\mathrm{Pb}$.

Tujuan dari studi literatur ini yakni diketahuinya sumber-sumber $\mathrm{Pb}$ yang terdapat di lingkungan dan diketahui dampak $\mathrm{Pb}$ terhadap kesehatan manusia.Adapun sebagai ruang lingkup dalam studi literatur ini hanya melihat gambaran tentang dampak $\mathrm{Pb}$ terhadap kesehatan menusia akibat adanya logam Timah hitam $(\mathrm{Pb})$ di lingkungan.

\section{SUMBER PENCEMARAN TIMAH HITAM (Pb) DI LINGKUNGAN.}

Timah hitam $(\mathrm{Pb})$ tergolong kedalam logam berat, yang dalam sistem periodik unsur ini terletak pada unsur golongan IV A, dan periode ke 6. Di alam $\mathrm{Pb}$ terdapat dalam bentuk senyawa sulfat $\left(\mathrm{PbSO}_{4}\right)$, karbonat $\left(\mathrm{PbCO}_{3}\right)$ dan sulfida $(\mathrm{PbS})$. Biji $\mathrm{Pb}$ yang utama adalah galena yang mengandung $\mathrm{PbS}$. $\mathrm{Pb}$ dapat diperoleh dengan memanaskan $\mathrm{PbS}$ pada suhu tinggi, kemudian $\mathrm{PbO}$ yang terbentuk direduksi dengan karbon, untuk memurnikannya dari logam lain, maka dilakukan elektrolisa sehingga menghasilkan

\footnotetext{
*Staf pengajar Politeknik Kesehatan Padang
} 
$\mathrm{Pb}$. Penggunaan $\mathrm{Pb}$ dalam industri kimia cukup luas antara lain, dalam industri batery, industri keramik, industri cat (Clarke, 1981)

Selain itu meningkatnya konsentrasi $\mathrm{Pb}$ di udara dapat berasal dari hasil pembakaran bahan bakar bensin dalam berbagai senyawa $\mathrm{Pb}$ terutama $\mathrm{PbBrCl}$ dan $\mathrm{PbBrCl}$.2PbO. Senyawa $\mathrm{Pb}$ halogen terbentuk selama pembakaran bensin, karena dalam bensin yang sering ditambahkan cairan anti letupan (anti ketok) yang terdiri dari $62 \%$ TEL, $18 \%$ etildiklorida dan $2 \%$ bahan-bahan lainnya.Senyawa yang berperan sebagai zat anti ketok adalah timbal oksida. Timbal oksida ini terdapat dakam partikel-partikel yang tersebar dala ruang bakar bensin . Senyawa $\mathrm{Pb}$ sukar larut dalam air tetapi mudah larut dalam minyak atau lemak (Fardiaz, 1992).

Tujuan penambahan bahan tersebut untuk mendapatkan tingkat oktan yang lebih tinggi, agar pemakaian bahan bakar bensin lebih ekonomis. Pada proses pembakaran mesin, senyawa ini dilepaskan dalam bentuk partikel melalui asap gas buang kendaraan bermotor ke udara, dimana sebagiann besar mengandung partikel $\mathrm{Pb}$ berdiameter dibawah 1 mikron. Besarnya ukuran partikel tersebut merupakan batas ukuran partikel yang dapat diserap melalui pernafasan.

Pada proses pembakaran mesin yang menggunakan bahan bakar bensin, dihasilkan gugus radikal bebas yang dapat menyebabkan letupan pada mesin, sehingga mengakibatkan menurunnya efisiensi mesin. Untuk mengatasi hal tersebut ditambahkan bahan berupa TEL atau TML. Tujuannya adalah untuk mengikat radikal bebas yang terbentuk selama proses pembakaran. Bahan tersebut akan bereaksi dengan gugus radikal bebas, dan menghalangi terjadinya reaksi pembentukan $\mathrm{PbO} . \mathrm{Pb}$ dalam bensin akan bereaksi dengan oksigen dan bahanbahan pengikat, selanjutnya dikeluarkan melalui sistem pembuangan dalam bentuk partikel. Partikel yang mengandung $\mathrm{Pb}$ akan diemisikan ke dalam lingkungan, sehingga menyebabkan terjadinya pencemaran udara oleh $\mathrm{Pb}$ (Kumar, De, 1979).

\section{Dampak Pencemaran Logam Timah Hitam (Pb) Terhadap Kesehatan}

Timah hitam $(\mathrm{Pb})$ merupakan bahan toksik yang mudah terakumulasi dalam organ manusia dan dapat mengakibatkan gangguan kesehatan berupa anemia, gangguan fungsi ginjal, gangguan sistem syaraf dan otak dan kulit (Kumar,De, 1979).

Selama dalam darah $\mathrm{Pb} 90 \%$ terikat pada sel darah merah, akibatnya sintesis hemoglobin terhambat, karena dapat menghalangi enzym aminolaevulinic acid dehidratase (ALAD) untuk proses sintesa tersebut, dan anemia biasa bisa terjadi dan umur sel darah merah lebih pendek. Terhadap syaraf mengakibatkan menurunnya kecepatan konduksi syaraf(Malaka, 1994).

$\mathrm{Pb}$ yang masuk ke dalam tubuh dapat dalam bentuk $\mathrm{Pb}$-organik seperti tetra etil $\mathrm{Pb}$, dan $\mathrm{Pb}$ anorganik seperti oksida $\mathrm{Pb}$. Toksisitas $\mathrm{Pb}$ baru akan terlihat bila orang mengkomsumsi $\mathrm{Pb}$ lebih dari $2 \mathrm{mg}$ perhari, ambang batas dari $\mathrm{Pb}$ yang boleh dikonsumsi adalah $0,2-2,0 \mathrm{mg}$ perhari
(Darmono, 1995).

$\mathrm{Pb}$ yang masuk ke dalam tubuh tidak semua dapat tinggal di dalam tubuh, kira-kira 5\% -10\% dari jumlah yang tertelan akan diadsorbsi oleh saluran pencernaan dan sekitar 5\% dari 30\% yang terserap lewat pernafasan akan tinggal di dalam tubuh. $\mathrm{Pb}$ yang tertinggal di dalam tubuh akan mengumpal terutama di skeleton (90-95\%). Untuk menentukan seseorang keracunan $\mathrm{Pb}$ dilakukan analisis kandungan $\mathrm{Pb}$ dalam darah (Fardiaz, 1992).

Intoksikasi $\mathrm{Pb}$ yang memerlukan perhatian berlebih adalah terjadinya paparan konsentrasi rendah dan berlangsung lama sehingga menimbulkan efek subklinik. Seperti halnya substansi-substansi toksik lain, efek $\mathrm{Pb}$ berhubungan dengan konsentrasi paparannya. Pada konsentrasi yang tinggi menyebabkan keracunan akut yang ditandai dengan gejala klinis. Hal ini perlu diwaspadai larena $\mathrm{Pb}$ mempunyai sifat afinitas yang kuat terhadap gugus sulfuhidril dari sistein, gugus amino dari lisin, gugus karboksil dari asam aspartat dan glutamat, dan gugus hidroksil dari tirosin. $\mathrm{Pb}$ juga dapat berikatan dan memodifikasi struktur tertiter protein dengan demikian menginaktifkan properti enzimatik, terlebih lagi enzim-enzim yang kaya akan gugus -SH.Oleh sebab itu dapat dikatakan bahwa setiap atom $\mathrm{Pb}$ dapat menginduksi kerusakan biokimia tubuh (Manahan,1992)

Efek sub klinik dari $\mathrm{Pb}$ secara jelas terjadi pada sistem syaraf dan hematopoetik. Pada sistem syaraf menyebabkan difungsi susunan syaraf, gangguan motorik dan perubahan perilaku. Efek neorologik ini terjadi pada dosis $\mathrm{Pb}>30 \mu \mathrm{g}$. Sedangkan efek hematologik (sistesis heme) terjadi pada konsentrasi yang jauh lebih rendah dari konsentrasi tersebut. Apabila gangguan berlanjut akan terjadi efek neorologik dan efek-efek lainnya dapat mengakibatkan anemia, dan terhadap syaraf mengakibatkan menurunnya kecepatan konduksi saraf( Malaka, 1994).

Berbagai perubahan anatomi akibat keracunan $\mathrm{Pb}$ baik pada sistem syaraf pusat maupun perifer telah banyak dilaporkan. Karena perkembangan $\mathrm{Pb}$ ensefalopati lebvih sering ditemukan pada anak dari pada orang dewasa, kebanyakan penelitian dilakukan terhadap pengaruh toksisitas $\mathrm{Pb}$ pada sistem syaraf pusat yang terjadi pada masa pertumbuhan anak (Frank, 1991).

Telah ditetapkan bahwa Tolerable Weekly Intake adalah $25 \mu \mathrm{g} / \mathrm{kg} \mathrm{BB}$, nilai ini merujuk pada $\mathrm{Pb}$ yang berasal dari semua sumber pencemar dan berlaku untuk semua usia. Penentuan nilai tersebut berdasarkan perkiraan penyerapan perhari sebesar 3-4 $\mu \mathrm{g} / \mathrm{kg}$ BB pada bayi dan anak dan tidak berasosiasi dengan $\mathrm{Pb}$ dalam darah. Sedangkan untuk konsentrasi $\mathrm{Pb}$ dalam darah WHO merekomendasikan konsentarsi $20 \mu \mathrm{g} / \mathrm{dl}$ untuk semua populasi dengan asumsi rata-rata $\mathrm{Pb}$ ambient 0,5-1,0 $\mu \mathrm{g} / \mathrm{m}^{3}$ pertahun (WHO, 1995).

Kadar $\mathrm{Pb}$ dalam darah adalah merupakan suatu keseimbangan yang dinamis, antara pemaparan, retensi serta pelepasan. Pada pemaparan yang telah berlangsung lama, maka kadar $\mathrm{Pb}$ darah tersebut merupakan indikator yang terbaik,lebih dijelaskan bahwa 15 ton $\mathrm{Pb}$ yang diemisikan di Los Angeles, didapatkan konsentrasi $\mathrm{Pb}$ udara sebesar $2,5 \mu \mathrm{g} / \mathrm{m}^{3}$, sementara pada kegiatan jam sibuk dan padat lalu lintas, konsentrasi $\mathrm{Pb}$ dapat meningkat sampai 
$45 \mu \mathrm{g} / \mathrm{m}^{3}$. Pada penduduk perkotaan kadar $\mathrm{Pb}$ darah adalah perkotaan sebesar $20 \mu \mathrm{g} / 100 \mathrm{ml}$, sedangkan pada penduduk pedesaan hanya sebesar $15 \mu \mathrm{g} / 100 \mathrm{ml}$ (WHO, 1995).

Penelitian Suksmerri tahun 2005, tentang Analisis Lingkungan Kerja pada Bengkel Cat Mobil di Kota Padang, hasil pengukuran lingkungan kimia yakni terhadap partikel (debu) dan logam-logam yang terkandung dalam partikel seperti, Timah hitam (Pb), Kadmium (Cd) dan Krom (Cr), dari 20 lokasi yang diteliti diantaranya 11 lokasi telah melebihi dari baku mutu yang ditetapkan yaitu $(\mathrm{Pb}=0,1$ $\mathrm{mg} / \mathrm{m}^{3}, \mathrm{Cd}=0,2 \mathrm{mg} / \mathrm{m}^{3}$ dan $\left.\mathrm{Cr}=0,1 \mathrm{mg} / \mathrm{m}^{3}\right)$, dalam hal ini adanya logam $\mathrm{Pb}$ di lingkungan udara berdasal dari debu cat mobil.

\section{Toksisitas Pb Dosis Tendah terhadap Tingkah Laku Anak}

Dewasa ini sarana pencegahan pencemaran lingkungan telah berkembang dengan cepat sehubungan dengan ditemukannya tekmnologi industri dan pengurangan penggunaan bahan penyebab pencemaran polutan $\mathrm{Pb}$, termasuk mengurangi kandungan dalam beberapa industri seperti industri cat. Hal ini menyebabkan kasus keracunan $\mathrm{Pb}$ secara akut akan berkurang, tetapi kecenderungan keracunan kronis $\mathrm{Pb}$ masih merupakan kasus yang perlu diwaspadai (Darmono,1994).

Dalam penelitian Needleman dkk (1979) mempelajari pengaruh kronis toksisitas $\mathrm{Pb}$ pada anak umur 6-7 tahun berdasarka analisis kandungan $\mathrm{Pb}$ pada giginya yang tanggal dan dikelompokkan menurut besarnya konsentrasi $\mathrm{Pb}$. Konsentrasi $\mathrm{Pb}$ diatas $24 \mathrm{ppm} \mathrm{Pb}$ dan konsentrasi dibawah $6 \mathrm{ppm} \mathrm{Pb}$, masing-masing sebagaim kelompok kandungan $\mathrm{Pb}$ tinggi dan rendah. Hasil tes berdasarkan kecerdasan (IQ) menunjukkan bahwa anak yang kandungan $\mathrm{Pb}$ dalam giginya tinggi ternyata kecerdasan (IQ) lebih rendah dari pada yang konsentrasi

\section{DAFTAR BACAAN}

Browne D.R., A Husni, Risk M.J.1999. Airbone lead and particulat levels in Semarang.Indonesia and potential health impacks. The Science of the Total Environment.

Clarke, M.L., D.G.Harvey. 1981. Lead in: Veterinary Toxicology $2^{\text {nd }}$ " The English Language Book Society, Bailliere Tindall.

Darmono. Logam dalam sistem biologi makhluk hidup.UI. Press.jakarta

Fran, C, Lu.1997. Toksikologi Dasar.Asas, Organ Sasaran dan Penilaian Resiko, Edisi kedua. Jakarta

Fardiaz, Srikandi.1992.Polusi Air dan Udara. Yogyakarta: Kanisius

Hariono, B. 1991. A Study of Lead (Pb) levels in animals and the Environment with particular reference to the fruit bat.Thesis pada University of Queensland, Brisbane, Australia

Kumar De Anil. 1979.Environmental Chemistry. New Delhi Bangalore Bombay Calcuta : Wiley and Sons.

Malaka, Tan.1994. Biomonitoring Proceding Simposium Pantauan Biologik dalam Proteksi Kesehatan Tenaga Kerja. Jakarta :Kedokteran UI. EGC

Manahan S.E.1992. Toxicological chemistry. New York :
$\mathrm{Pb}$ rendah.

Penelitian selanjutnya dengan mempelajari fungsi dan kebiasaan dan penampilannya di sekolah pada anak umur 6-7 tahun. Ternyata hasil sangat nyata, dimana anak yang mempunyai kandungan $\mathrm{Pb}$ tinggi pada giginya menunjukkan resiko dikeluarkan dari sekolah karena tidak mampu mengikuti pelajaran. Anak yang menderita toksisitas $\mathrm{Pb}$ kronis tersebut menunjukkan kelemahan daya pikir, lamban, sulit menangkap pelajaran, sulir berkonsentrasi sehingga mereka tidak dapat melanjutkan sekolah ke tingkat lebih tinggi (Needleman dkk, 1990)

Walaupun tidak menunjukkan gejala keracunan, tetapi pengaruhnya sangat mengkhawatirkan,baik berupa penurunan neurobihaviour maupun daya intelektualitasnya. Hasil penelitian tersebut masih dalam pertimbangan, karena biasanya anak yang menderita keracunan kronis $\mathrm{Pb}$ kebanyakan berasal dari keluarga yang kurang mampu yang dalam kehidupan sehari-hari kurang memperhatikan kualitas lingkungan.

Dari studi literatur ini dapat ditarik kesimpulan, bahwa lingkungan yang mengandung $\mathrm{Pb}$ dengan konsentrasi tinggi, dapat berdampak terhadap gangguan kesehatan manusia, seperti halnya terjadi peningkatan kadar $\mathrm{Pb}$ dalam darah yang mengakibatkan gangguan terhadap sistem syaraf pusat, dan dapat mengurangi kecerdasan (IQ) bagi anak-anak.

Saran yang dapat dikemukakan yakni mengurangi keterpaparan dengan udara yang mengandung $\mathrm{Pb}$ berkonsentrasi tinggi, serta lebih memperhatikan dalam pelestarian lingkungan seperti penanaman tumbuhan hijau di sepanjang jalan raya, dimana pohon berperanan dalam mengurangi pencemaran udara, salah satunya adalah partikel yang bersumber dari kendaraan bermotor.

Lewis Publishers.

Needleman, H.L., dkk. 1979.Defisit in psichologic and classroom performance of children with elevated dentine lead levels. New England J OF Medicine.

Needleman, H.L., dkk. 1979.The longterm effects of exposurto low doses of lead in childhood. New England J OF Medicine

Palar, H. 1994. Pencemaran dan Toksikologi logam berat. Penerbit Rineka Cipta. Jakatta

Peratutan Pemerintah Republik Indonesia Nomor 41 Tahun 1999. Tentang Pengendalian Pencemaran Udara.

Suksmerri .2005. Analisis Lingkungan Kerja pada Bengkel Cat Mobil di Kota Padang. Tesis.Program Studi Ilmu Lingkungan. Pascasarjana.UNP:Padang

WHO. 1989. Lead. Environmental Aspects. Environmental Health Criteria 85, Geneva.

Widiati, Wiwik. 1994. Pengaruh Gas Buang Kendaraan Bermotor Terhadap Kadar Timbal Darah Pedagang Kaki Lima di Yogyakarta. Yogyakarta: Tesis Program Pascasarjana UGM. 